\title{
Two New Miospore Species from the Lower Permian of Iraq
}

\author{
Maha A. Al-Hasson \\ Geology Department \\ College of Science \\ Mosul University
}

(Received 30/12/2008, Accepted 7/5/2009)

\begin{abstract}
Two new miospore species are described in detail from samples of Ga'ara Formation of Early Permian (Kungurian) age in borehole (WKF-1) in south Iraq. These are Calamospora delicata and Spelaeotriletes kefelensis.
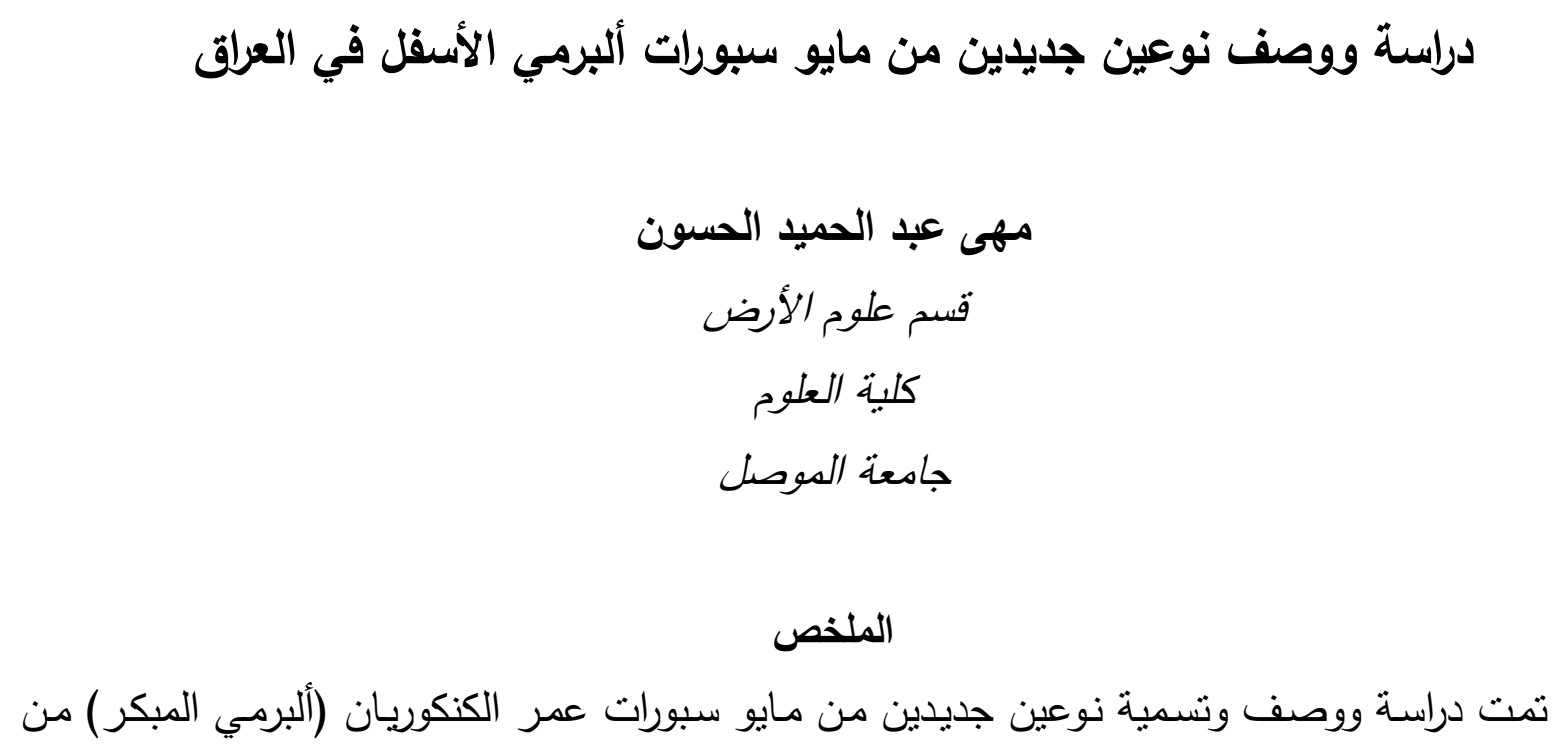

تكوين الكعرة من بئر غرب الكفل-1 (WKF-1) في جنوب العراق وهذين النوعين هما: Calamospora Spelaeotriletes kefelensis g delicate
\end{abstract}

\section{INTRODUCTION}

Paleozoic strata are known from subsurface sections in many keyholes in the Ga'ara depression, western Iraqi Desert. The borehole WKF-1 is located approximately $40 \mathrm{~km}$ south of Karbala city (Fig.1). Drilling has penetrated at 5875m depth the uppermost part of Ga'ara Formation of Upper Pennsylvanian-Lower Permian (Kasimovian-Kungurian) age according to (Nader et al., 1993; 1994). The Ga'ara Formation consists of sandy marl, claystone, siltstone with intercalation of clayey coals and sandstone.

The studied samples represent the core intervals (5867-5872) $\mathrm{m}$ which is composed of shaly sand immediately underlying the Chia Zairi Formation (Fig.2). 
The thickness of the studied section is $5 \mathrm{~m}$ representing the uppermost part of the Ga'ara Formation of upper Early Permian (Kungurian) age according to (Nader and Yousif, 2000).

The aim of the present study is to describe and illustrate two new species of trilete miospores from the Ga'ara Formation of Early Permian (Kungurian) age.

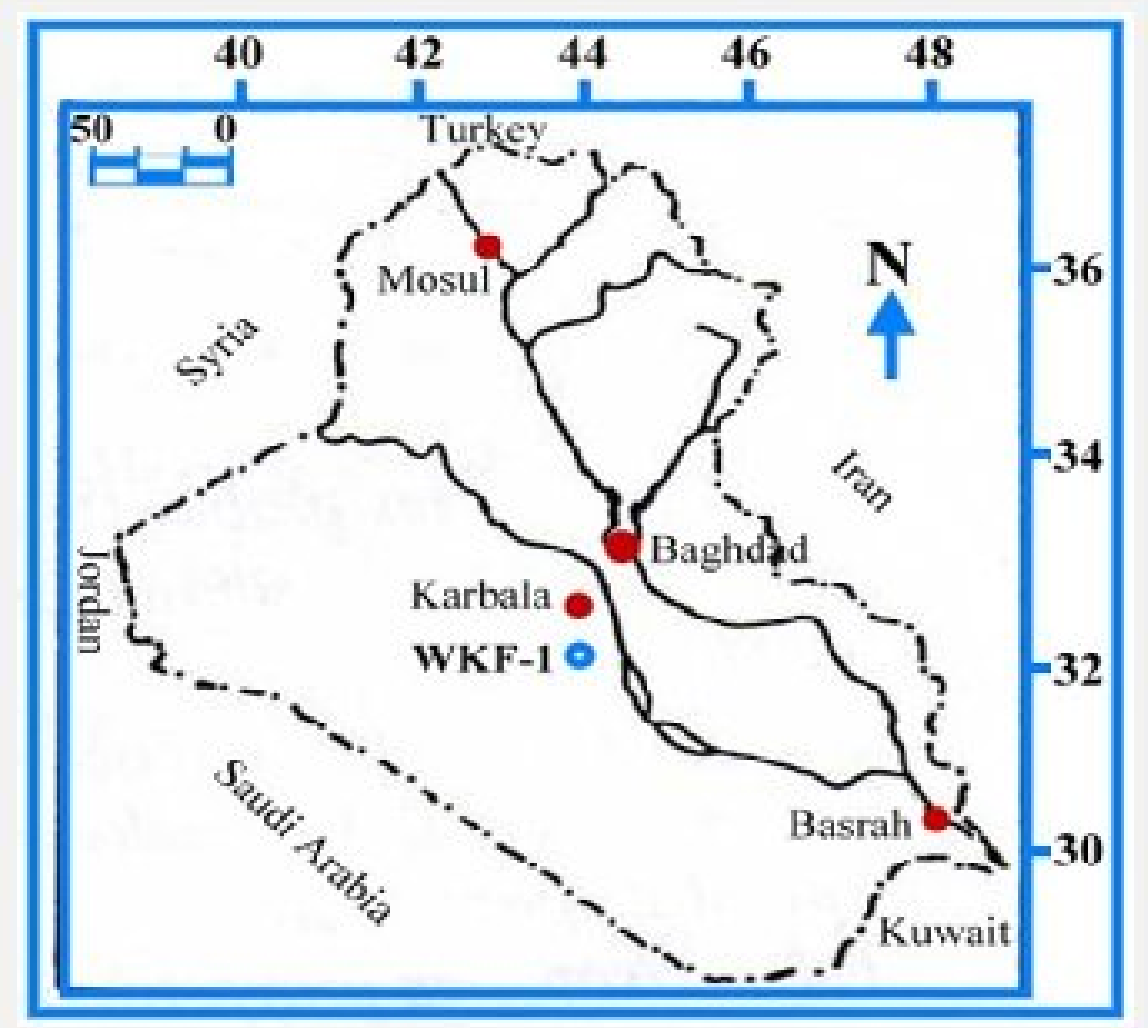

Fig.1: Location map

The samples of this study were provided by the Oil Exploration Company which were subjected to conventional palynological preparatory techniques. The spore specimens illustrated in the present paper are deposited in the Department of Geology, College of Science, Mosul University. Optical photographs were taken with Olympus BH-2 microscope and the state coordinates quoted relate to that microscope, with slide label on the left unless the coordinates are prefixed by (R) when the slide label on the right. 


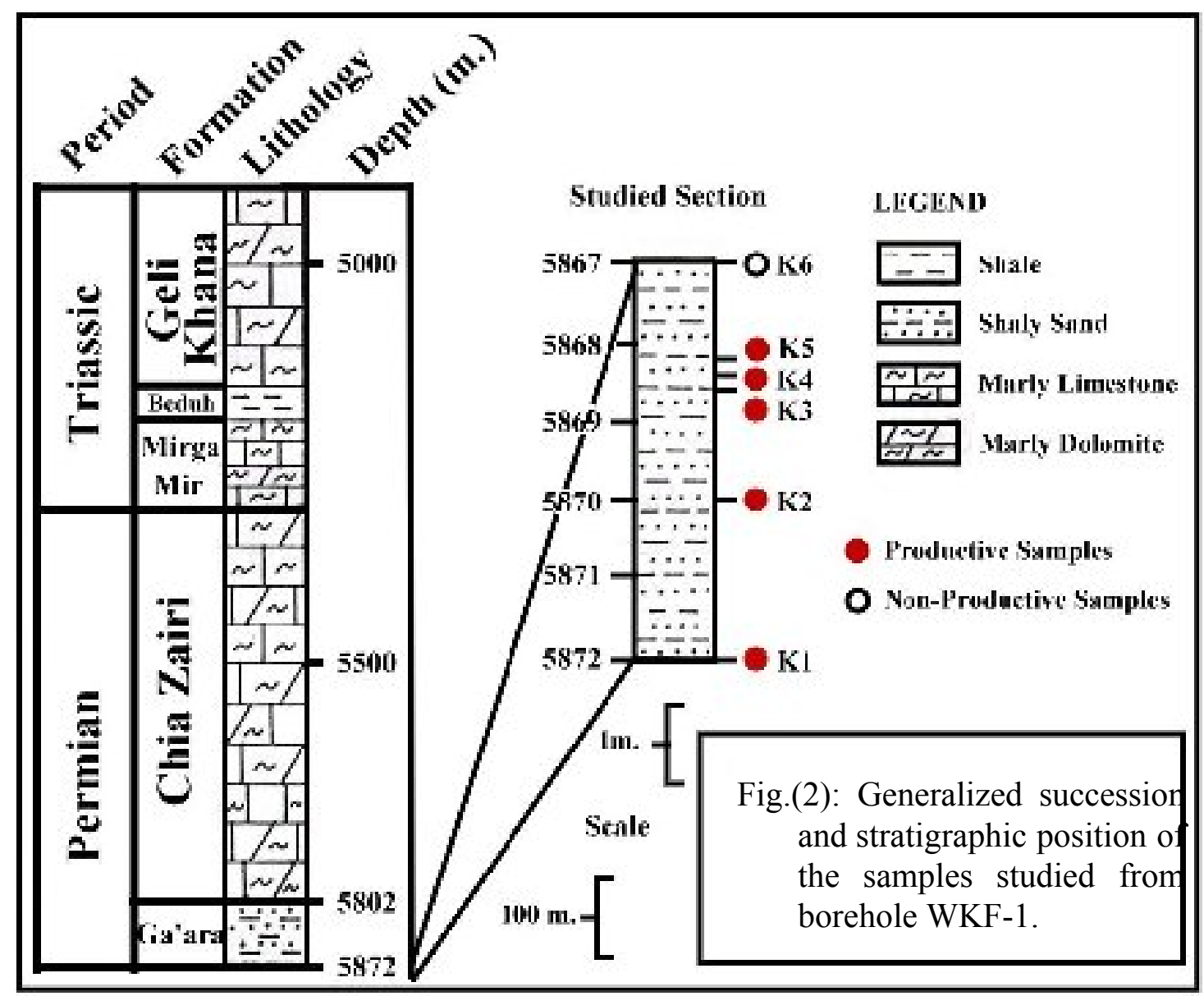

Fig.2: Generalized succession and stratigraphic position of the samples studied from borehole WKF-1

\section{SYSTEMATIC PALYNOLOGY}

The systematic study is based on that proposed by Potonie (1970), and that of Traverse (1988). The descriptive terminology are those suggested by Grebe (1971).

Anteturma PROXIMEGERMINATES Potonie 1970

Turma TRILETES Reinsch emend. Dettmann 1963

Suprasubturma ACAVATITRILETES Dettmann 1963

Subturma AZONOTRILETES (Luber) Dettmann 1963

Infraturma LAEVIGATI (Bennie and Kidston) Potonie 1956

Genus CALAMOSPORA Schopf, Wilson and Bentall 1944

Type species: Calamospora hartungiana Schopf, in Schopf, Wilson and Bentall 1944

Calamospora delicata sp. nov.

P1.1, Fig. 1-2 
Derivation of name: Latin, delicata, thin, describing its thinner exine

Holotype: Slide K4, R.127/10.6, size (44) $\mu$ m, Pl.1, Figs. 1-2

Description: Miospore radial, trilete; amb circular occasionally subcircular due to compression folds; periphery smooth to slightly undulate. Laesurae indistinct to very weakly defined, simple almost straight, length (3-7) $\mu \mathrm{m}$, usually unequal (the shorter being often inconspicuous or very weakley defined giving an appearance of dilete laesurae (Text-Fig.1). Exine acavate, laevigate, thin less than $(0.3) \mu \mathrm{m}$ thickness, commonly distorted by irregular scattered small scale compression folds, giving wrinkle ornamentations with less densely big scale folds that parallel to the equatorial margin of miospore making an equatorial darkening and thickening due to the folding.

Size range: $40(42) 45 \mu \mathrm{m}$ diameter (based on 20 specimens)

Comparison: Calamospora delicata sp. nov. differs from other species of the genus Calamospora Schopf, Wilson and Bentall 1944 in having a thinner distorted exine by many small and big scale compression folds, giving wrinkle ornamentations (its thickness less than the minimum range thickness of Calamospora species), and it differs in the nature of the laesurae which appear to be weakly defined trilete to dilete mark.

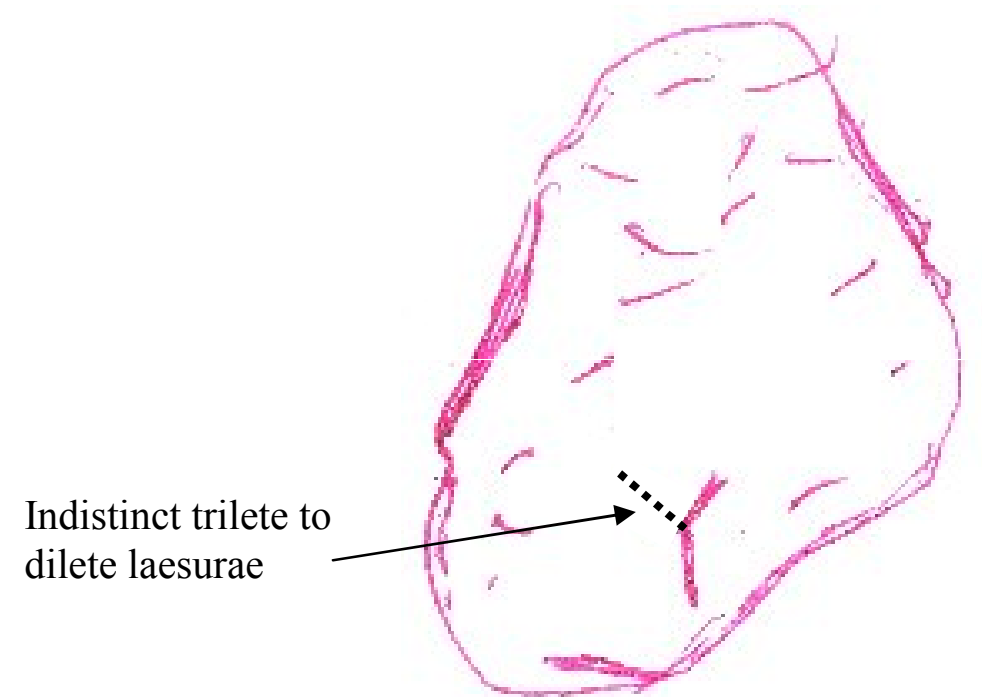

Text-Fig.1: Calamospora delicata sp. nov.,

Diagramatic reconstruction of proximal view showing the position of indistinct trilete to dilete laesurae

Suprasubturma PSEUDOSACCITRILETES Richardson 1965

Subturma MEMBRANATITRILETES Neves and Owens 1966

Infraturma CONTINUATI Neves and Owens 1966

Genus SPELAEOTRILETES Neves and Owens 1966

Type species Spelaeotriletes triangulatus Neves and Owens 1966

Spelaeotriletes kefelensis sp. nov.

$$
\text { P1.1, Figs .3-6 }
$$


Holotype:Slide K5, R.114.6/1.9; exoexine size (44) $\mu$ m, intexine size (27) $\mu \mathrm{m}$, Pl.1, Fig.3

Derivation of name: kefelensis, according to the geographical site of the borehole West Kefel.

Description: Miospore radial, trilete, amb oval to rounded triangular, in some cases appears to be subcircular. Laesurae normally indistinct, rays simple, straight, extending almost to the margin of intexine and terminating in curvaturae imperfectae. Intexine thin, its outline is conformable with the outline of the exoexine, comprising (0.5-0.6) of the miospore diameter, the equatorial margin of the intexine frequently darkened and thickened. Proximal surface laevigate except at the radial extremities. Distal surface and equator ornamented with variable elements which are mostly small, rounded and flat topped baculae with subordinate coni, grana and less commonly spinae. Ornamentation often discrete except grana which may be fused to form short regular shaped regulae. Elements (0.5-1) $\mu \mathrm{m}$ in height and width. Equatorial margin of the exoexine may form a distinct wall thickness and darkness feature.

Size range: Exoexine 42(44)50 $\mu \mathrm{m}$; intexine 20(25)28 $\mu \mathrm{m}$ (based on 10 specimens)

Comparison: Spelaeotriletes kefelensis sp. nov. is similar to Spelaeotriletes balteatus (Playford) Higgs 1975, but the former differs in having smaller size and finer ornamentation which is mainly baculate rather than apiculate (connate) elements. Spelaeotriletes obtusus Higgs 1975 and Spelaeotriletes resolutus Higgs 1975 differ in lacking the apiculate ornamentation.

\section{REFERENCES}

Gerbe, H. 1971. Terminologie Morphographique Recommandee et Methode de Description Des Spores. In C.I.M.P. Microfossiles Organiques du Paleozoique. 4Les Spores C.N.R.S. edit, pp. 7-34.

Higgs, K. T., 1975. Upper Devonian and Lower Carboniferous Miospore Assemblages from Hook Head, County Wexford, Ireland. Micropaleontology, Vol. 21, pp.393419.

Nader, A. D., Khalaf, F. H. and Yousif, R. A., 1993. Palynology of the Upper Part of the Ga'ara Formation in the Western Iraqi Desert. Mutah Journal for Research and Studies. Vol. 8, No. 4, pp. 77-137.

Nader, A. D., Khalaf, F. H. and Yousif, R. A., 1994. Palynology of the Lower Part of the Ga'ara Formation in Borehole KH5/1, Western Iraqi Desert. Abhath Al-Yarmouk. Vol.3, No.1, pp. 193-207.

Nader, A. D. and Yousif, R. A., 2000. Palynological Study of the Part of WKF-1 Borehole, South Iraq. Raf. Jour. Sci.,Vol.11, No.1, pp. 48-55.

Potonie, R. 1970. Synopsis Der Gattungen Der Sporae Dipersae, V. Beih. Geol. Jb., Vol. 87, pp.1-222. 
Schopf, J. M. Wilson, L. R. and Bentall, R.,1944. An Annotated Ssynopsis of Paleozoic Fossil Spores and the Definition of Generic Groups. Illinois State Geol. Survey, Rept. Invest., Vol. 91, pp 1-66.

Traverse, A., 1988. Paleopalynology. Publ. Unwin Hyman Ltd. London, UK, 599 p.

\section{Plate 1}

All photos are shown at $\mathrm{x} 1000$

Fig. 1-2 Calamospora delicata sp. nov.

1-Holotype, Slide K4, R.127/10.6

2-Slide K3, R.128.3/8.3

Fig. 3-6 Spelaeotriletes kefelensis sp. nov.

3-Holotype, Slide K5, 114.6/1.9

4-Slide K5, R.127.2/14

5-Slide K5, 120/8.2

6-Slide K5, 126/2.2 
Plate 1

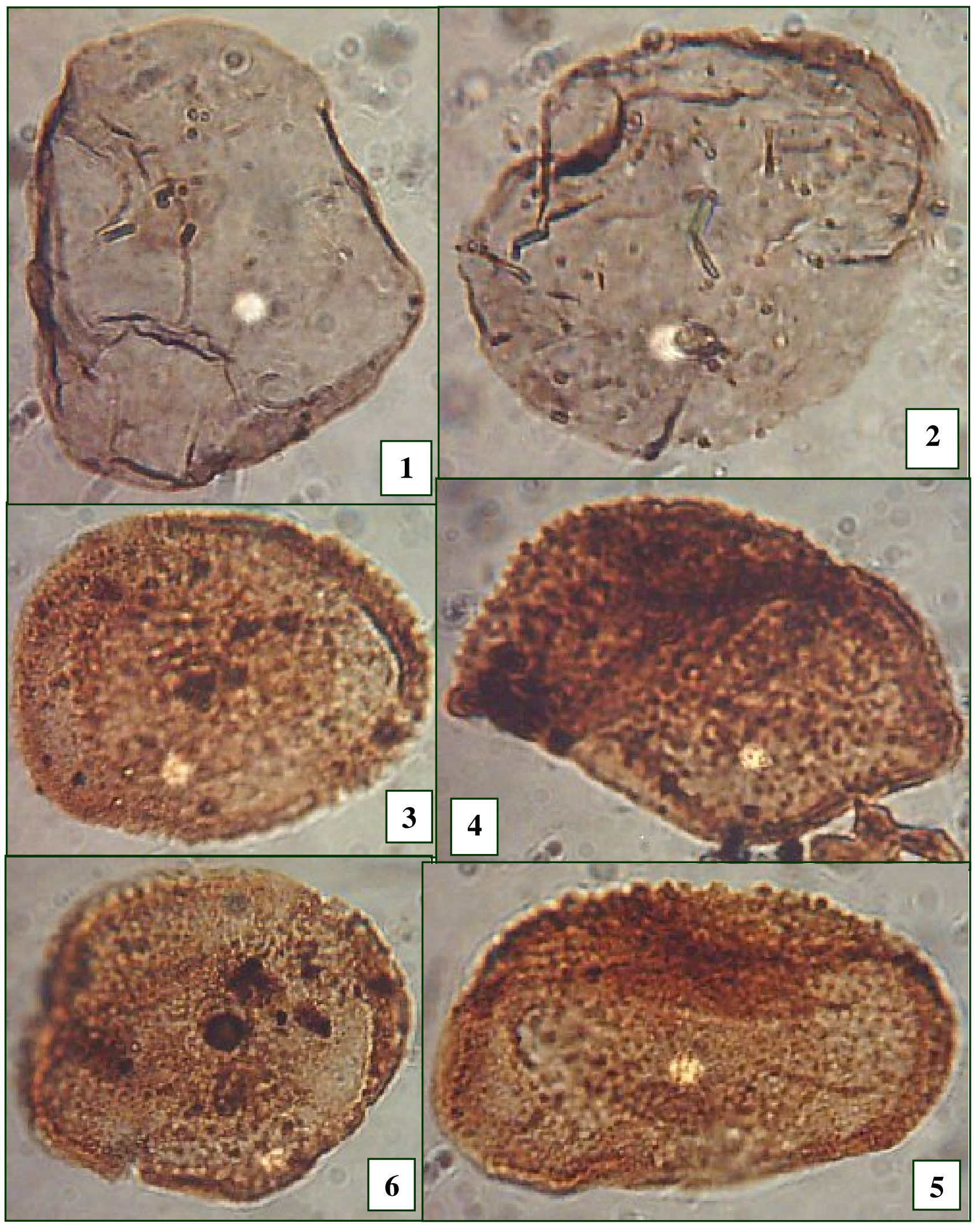

